\title{
GAMBARAN PENGASUHAN IBU DALAM MENGEMBANGKAN PERILAKU ADAPTIF SISWA TUNAGRAHITA
}

\author{
Rani Rishanty, Weny Savitry S. Pandia \\ Fakultas Psikologi, Universitas Katolik Indonesia Atma Jaya \\ J1. Jendral Sudirman No.51, Setiabudi, Jakarta Selatan, Daerah Khusus Ibukota Jakarta 12930 \\ rani.rishanty@yahoo.com
}

\begin{abstract}
The purpose of this study is to describe mother's parenting in developing adaptive ability on children with moderate to severe mental retardation. This research was a qualitative research. The subjects were three mothers who have children with moderate to severe mental retardation at SDLB X Jakarta. The subjects were selected using purposive sampling technique. Data were collected using interview and observation. The observation data was only used to support the suitability of interview data. The results showed that three participants had less positive parenting in developing students' adaptive abilities. This was shown from the acceptance and demandingness of the mother to each child. Three participants taught with verbal and provide direct assistance to student. This situation happens when students was unable to perform daily activities. The subjects also had no specific rules and consequences to support students' adaptive skills. Several factors that influence those condition were unappropriate expectation of mothers with their children and limited knowledge about characteristic of children with mental retardation. Thus, some areas of students' adaptive ability didn't grow optimally.
\end{abstract}

Keywords: mother's parenting; adaptive skill; mental retardation; SDLB-C

\begin{abstract}
Abstrak
Tujuan dari penelitian ini yaitu untuk mengetahui gambaran pengasuhan ibu dalam mengembangkan perilaku adaptif para siswa tunagrahita sedang hingga berat. Penelitian ini merupakan penelitian kualitatif. Subjek penelitian terdiri dari tiga orang ibu yang memiliki anak tunagrahita sedang hingga berat di SDLB X di Jakarta yang dipilih melalui teknik purposive sampling. Dari ketiga responden tersebut, peneliti melakukan pengumpulan data dengan teknik wawancara dan observasi, yang mana data observasi dianggap sebagai data penunjang kesesuaian data wawancara. Dilihat dari hasil penelitian, ketiga partisipan menampilkan pengasuhan yang kurang positif dalam mengasah perilaku adaptif siswa. Hal ini dilihat dari respon ibu serta aturan yang kurang tepat dalam mengasah perilaku adaptif ketiga siswa tunagrahita. Ketiga partisipan cenderung menampilkan pengajaran secara verbal serta memberikan bantuan langsung kepada siswa saat siswa tidak mampu melakukan kegiatan sehari-hari. Ketiga partisipan juga tidak memiliki aturan serta konsekuensi tertentu dalam mendukung perilaku adaptif siswa. Adapun beberapa faktor yang mempengaruhi hasil tersebut, antara lain adanya harapan yang kurang sesuai dengan karakteristik anak, pengetahuan partisipan yang terbatas terkait pengasuhan anak tunagrahita, serta keyakinan diri mereka yang kurang terkait pengasuhan anak tunagrahita. Kondisi ini yang berdampak pada beberapa area perilaku adaptif siswa nampak belum berkembang.
\end{abstract}

Kata kunci: pengasuhan ibu; perilaku adaptif; tunagrahita; SDLB-C

\section{PENDAHULUAN}

Setiap orangtua menginginkan anak yang sehat tanpa kekurangan satu apapun. Namun pada kenyataannya, beberapa anak terlahir dengan kondisi disabilitas atau pada masa perkembangannya mengalami disabilitas. Berdasarkan hasil pencatatan Badan Pusat Statistik (Kementerian Sosial, 2015), jumlah penyandang disabilitas di Indonesia mengalami peningkatan di setiap tahunnya.
Pada tahun 2013 tercatat 5,8 juta penduduk Indonesia yang mengalami disabilitas. Angka ini terus mengalami peningkatan hingga 9,46 juta penduduk di tahun 2015. Peningkatan terbesar berada pada individu penyandang tunagrahita.

Dilihat dari pengertiannya, anak-anak dengan penyandang tunagrahita dapat dikategorikan sebagai anak yang memiliki keterbatasan dalam fungsi intelektual serta perilaku 
adaptif (Wolfe \& Mash, 2010). Terkait dengan fungsi intelektual, anak-anak ini cenderung memiliki kapasitas intelektual di bawah rata-rata (IQ 70 atau di bawahnya) (American Association on Intellectual and Developmental Disability, dalam Hallahan, Kauffman, \& Pullen, 2012). Adapun empat klasifikasi penyandang tunagrahita berdasarkan Skor IQ, antara lain mild retardation (50-70), moderate (di atas 3549), severe (20-35), dan profound (di bawah 20) (Hallahan, Kauffman, \& Pullen, 2012).

Karakteristik khas lainnya pada anak tunagrahita yaitu perilaku adaptifnya yang terbatas. Menurut Grossman (dalam Boundarantz-Utz \& Luciano, 1997), perilaku adaptif diartikan sebagai derajat keefektifan seorang anak untuk menjadi pribadi yang mandiri dan bertanggung jawab sesuai dengan usianya serta aturan-aturan dalam masyarakat. Dilihat dari pengertiannya, perilaku adaptif diperlukan oleh individu agar mereka tidak bergantung dengan orangorang sekitarnya atau tidak menampilkan perilaku yang melanggar standar norma yang ada. Ketika individu tunagrahita belum mengembangkan perilaku adaptif, maka mereka berisiko untuk mendapatkan penolakan dari teman sebayanya maupun masyarakat sekitarnya. Dilihat dari kondisi anak tunagrahita di Indonesia, penolakan tersebut rentan dimunculkan oleh lingkungan sekitar anak (UNICEF; Payne \& Patton, dalam Agustin \& Widyawati, 2012). Hal ini terjadi karena sebagian besar anak-anak penyandang tunagrahita belum mampu melakukan aktivitas sehari-hari secara mandiri.

Tingginya tingkat ketergantungan anak dalam melakukan aktivitas sehari-hari sebenarnya berkaitan dengan kemampuan intelektual anak tunagrahita yang tergolong rendah (Sloan \& Birch, dalam Wolfe \& Mash, 2010). Kondisi ini yang membuat anak tunagrahita memerlukan suatu pelatihan dengan treatment yang cocok serta metode pelatihan tertentu sedini mungkin. Tujuannya adalah agar mereka mampu mengembangkan kemandirian serta tanggung jawab secara personal maupun sosial.

Pembelajaran maupun pelatihan yang diperuntukkan bagi anak tunagrahita menjadi penting untuk dilakukan sedini mungkin, terutama saat mereka mulai memasuki sekolah dasar. Hal ini karena berkaitan dengan tuntutan pembelajaran mereka di sekolah dasar, khususnya di sekolah luar biasa (SLB). Sekolah luar biasa (SLB) bagi siswa tunagrahita dinamakan sebagai SLB-C. SLB-C ini sebenarnya memiliki mata pelajaran yang sama dengan sekolah regular. Namun mata pelajaran tersebut disesuaikan dengan tingkat kemampuan siswa tunagrahita. Mata pelajaran di SLB-C cenderung memiliki tingkat kesulitan yang lebih rendah dibandingkan dengan sekolah regular. Hal ini karena bidang akademis bukan menjadi fokus utama dalam pembelajaran mereka. Pada siswa tunagrahita sekolah dasar, keterampilan perilaku adaptif yang menjadi fokus utama dalam pembelajaran di SDLB-C. Hal ini diwujudkan dengan cara memberikan materi pembelajaran bina diri bagi anak tunagrahita di setiap minggunya.

Berdasarkan Departemen Pendidikan Nasional Direktorat Pendidikan Luar Biasa (dalam Agustin \& Widyawati, 2012), beberapa perilaku adaptif yang perlu dipelajari oleh siswa tunagrahita usia sekolah, antara lain kebersihan badan (mencuci tangan, cuci muka, cuci kaki, sikat gigi, dan buang air kecil/besar), makan dan minum (makan menggunakan tangan, makan menggunakan sendok, minum menggunakan gelas atau sedotan), berpakaian (memakai pakaian dalam, memakai kaos, memakai celana/rok, memakai kemeja, dan memakai kaos kaki serta sepatu), menolong diri (menghindari diri dari bahaya, seperti api atau benda tajam), serta komunikasi (aktivitas verbal dan non verbal). Perilaku adaptif ini yang kemudian dijadikan pembelajaran di berbagai SLB-C. Harapannya, siswa tunagrahita usia sekolah dapat menguasai perilaku adaptif tersebut, 
sehingga kelak menjadi pribadi yang lebih mandiri.

Dalam pembelajaran keterampilan perilaku adaptif di SDLB, siswa tunagrahita memerlukan beberapa strategi pembelajaran. Strategi pembelajaran tersebut antara lain melalui peragaan, pembiasaan, latihan, pengulangan, serta penguatan (Suparno dalam Helawati, 2016). Pada strategi peragaan, siswa tunagrahita memerlukan suatu pembelajaran dengan menggunakan alat peraga tertentu. Hal ini dikarenakan kondisi kemampuan intelektual mereka terbatas, sehingga siswa tunagrahita lebih kesulitan dalam memahami hal-hal yang bersifat abstrak. Pada strategi pembiasaan, anak-anak tunagrahita memerlukan pembelajaran yang sama setiap waktunya. Artinya adalah mereka memerlukan metode pembelajaran yang sama serta konsisten dilakukan diwaktu yang telah ditetapkan orangtua. Hal ini sebagai upaya agar siswa dapat lebih mudah untuk mengingat pembelajaran yang diberikan. Selain itu, siswa tunagrahita juga memerukan pembelajaran yang berulang-ulang. Adanya keterbatasan intelektual siswa tunagrahita, mereka memiliki keterbatasan dalam mengingat materi-materi yang baru dipelajari. Untuk itu, siswa tunagrahita memerlukan pengulangan tertentu saat diberikan pembelajaran (Mangunsong, 2012).

Strategi pembelajaran berikutnya yaitu dengan pemberian latihan serta penguatan (penghargaan) (Suparno dalam Helawati, 2016). Dalam pemberian latihan, siswa tunagrahita memerlukan latihan tertentu yang disesuaikan dengan kemampuan masingmasing siswa. Hal ini dilakukan agar siswa tunagrahita memiliki kemudahan dalam menangkap pembelajaran yang diberikan. Selanjutnya, pada strategi penguatan, siswa tunagrahita membutuhkan suatu pujian tertentu saat mereka berhasil dalam melakukan sesuatu. Tujuannya yaitu untuk membentuk perilaku yang diharapkan pada siswa tunagrahita. Dalam pemberian pujian tersebut, orangtua maupun guru perlu memperhatikan cara penyampaian pujian. Pada siswa tunagrahita, pemberian pujian hendaknya dilakukan secara verbal serta gerakan konkrit (Suparno dalam Helawati, 2016). Hal ini karena siswa tunagrahita memiliki keterbatasan dalam menangkap informasi yang bersifat abstrak. Dengan demikian, pujian yang bersifat konkrit perlu diberikan bagi para siswa tunagrahita. Tujuannya agar siswa tunagrahita memahami bentuk pujian yang diberikan oleh orangorang sekitarnya, sehingga berdampak pada munculnya perilaku yang diharapkan.

Pada pencapaian keberhasilan perilaku adaptif, adapun beberapa faktor yang sebenarnya mempengaruhi keberhasilan tersebut, yaitu faktor internal dan faktor eksternal. Faktor internal berkaitan dengan kemampuan kognitif siswa yang terbatas serta kelemahan motorik tubuh menjadi salah satu kendala bagi siswa untuk mempelajari berbagai keterampilan perilaku adaptif sehari-hari. Namun secara keseluruhan, siswa tunagrahita sebenarnya mampu untuk melakukan kegiatan harian secara mandiri serta hanya membutuhkan pengawasan yang minimal saat berpakaian ataupun ke kamar mandi (Tork, Lohrmann,\& Dassen, 2007). Hal tersebut dapat terwujud apabila siswa mendapatkan suatu bimbingan serta latihan yang tepat di rumah maupun di sekolah.

Terkait dengan faktor eksternal, sekolah tidak dapat berdiri sendiri tanpa adanya turut serta bantuan orangtua dalam usaha pencapaian perilaku adaptif yang optimal (Heward, 2013). Pentingnya peranan orangtua ini sebenarnya telah banyak dibuktikan dalam beberapa penelitian. Salah satunya yaitu penelitian yang dilakukan oleh Heward (2013) yang menyatakan bahwa segala program penanganan serta peningkatan kemampuan hidup anak berkebutuhan khusus sangat ditentukan oleh pengasuhan yang diberikan orangtua kepada anak mereka. Bahkan, pengasuhan juga menjadi salah satu faktor utama dalam perilaku adaptif yang ditunjukkan oleh para siswa tunagrahita (Eisenberg, Zhou, Spinrad, Valiente, Fabes, 
\& Liew, 2005; Frick, dalam Mahdavi, Esmaeilpour, \& Khajeh, 2013).

Baumrind (dalam Alizadeh, Talib, Abdullah, \& Mansor, 2011) menyebutkan bahwa pengasuhan merupakan suatu kegiatan kompleks yang mencakup banyak perilaku spesifik guna mempengaruhi perkembangan kepribadian, karakter, serta kompetensi anak Pengasuhan yang ideal ini menjadi penting ditampilkan oleh orangtua, khususnya yang memiliki anak disabilitas. Menurut Baumrind (dalam Dyches, Smith, Korth, Roper, \& Mandleco, 2012), pengasuhan yang ideal dapat dilihat dari beberapa perilaku yang ditunjukkan oleh orangtua kepada anaknya, seperti menampilkan unsur penerimaan, kehangatan, keterlibatan, kesensitifan, responsif, serta pemberian kesempatan bagi anak untuk berlatih secara konsisten. Namun, berbagai anggapan yang ditemukan oleh orangtua menjadi salah satu faktor tidak terwujudnya pengasuhan yang ideal (Bigner, 2002). Salah satunya yaitu anggapan orangtua bahwa anak tunagrahita selalu membutuhkan bantuan dalam melakukan kegiatan sehari-hari (Ulfatulsholihat, 2010). Kondisi ini yang kemudian berdampak pada pengasuhan mereka terhadap anak.

Menurut Baumrind (dalam Hong, Long, \& Rahman, 2015), terdapat dua dimensi pengasuhan yang dapat menggambarkan pengasuhan orangtua terhadap anak mereka. Dimensi pertama yaitu responsivitas. Responsivitas diartikan sebagai suatu gambaran bagaimana orangtu memberikan respon kepada anak. Respon tersebut dapat dilihat dari sejauh mana orangtua mengetahui kebutuhan anak mereka, keterlibatan mereka terhadap aktivitas anak, serta afeksi yang diberikan oleh orangtua kepada anak.

Terkait dengan kebutuhan anak, orangtua penting mengetahui apa saja yang memang dibutuhkan oleh masing-masing anak mereka (Baumrind dalam Suchman, Rounsaville, DeCoste \& Luthar, 2007). Kebutuhan ini tentu saja berkaitan pula dengan karakteristik dari anak itu sendiri. Dengan kata lain, ketika orangtua mengetahui karakteristik anak mereka, orangtua cenderung menampilkan pengasuhan yang sesuai dengan kebutuhan anak mereka. Hal ini tentu saja dapat berdampak pada perkembangan anak di segala bidang kehidupannya kelak. Berbeda dengan para orangtua yang tidak paham dengan kebutuhan anak mereka. Para orangtua tersebut cenderung menampilkan pengasuhan yang kurang tepat bagi anak. Hal ini karena pengasuhan yang diberikan cenderung tidak sesuai dengan kebutuhan anak mereka. Untuk itu, wawasan terkait kebutuhan anak perlu dimiliki oleh setiap orangtua.

Selanjutnya, dalam hal keterlibatan orangtua, orangtua perlu mengetahui kadar keterlibatan yang sesuai untuk diberikan kepada anak (Baumrind, dalam Suchman, Rounsaville, DeCoste \& Luthar, 2007). Orangtua yang kurang terlibat pada anak biasanya memiliki ciri-ciri, seperti tidak memperdulikan anak mereka (aktivitas maupun perkembangan anak), mengabaikan, bahkan menampilkan unsur penolakan terhadap anak. Di sisi lain, ada orangtua yang cenderung menampilkan keterlibatan penuh terhadap aktivitas anak. Orangtua tersebut biasanya menampilkan ciri utama, seperti melakukan sebagian besar aktivitas yang dilakukan oleh anak tanpa pemberian suatu penjelasan (Ling, 2008). Beberapa di antara mereka juga nampak membatasi tingkah laku anak, sehingga anak tidak memiliki kesempatan untuk bereksplorasi terhadap lingkungan sekitarnya.

Kondisi ini tentu saja dapat berdampak pada perkembangan anak. Salah satunya adalah anak bertumbuh menjadi sosok yang tidak mandiri. Lain halnya dengan orangtua yang menampilkan keterlibatan sesuai dengan porsinya. Orangtua tersebut cenderung memberikan suatu pengajaran bagi anak mereka saat mereka memutuskan untuk terlibat pada aktivitas anak (Baumrind dalam Suchman, Rounsville, DeCoste, \& Luthar, 2007). Hal ini tentunya dapat berdampak positif bagi perkembangan anak ke 
depannya. Anak bertumbuh menjadi pribadi yang mandiri dan tidak bergantung pada orang sekitarnya.

Terkait dengan afeksi, hal ini menjadi penting pula diberikan oleh orangtua kepada anak (Baumrind dalam Suchman, Rounsaville, DeCoste \& Luthar, 2007). Hal ini karena kasih sayang yang ditunjukkan oleh orangtua terhadap anak membuat anak merasa nyaman, menghilangkan kecemasan, membangun rasa aman, dan harga diri mereka. Selain itu, anak juga lebih mudah untuk belajar dan menerima standar yang ditetapkan oleh orangtua, dibandingkan dengan anak dari orangtua yang penuh penolakan. Salah satu bentuk kasih sayang yang umumnya ditunjukan oleh orangtua, yaitu berupa tindakan (pelukan) atau pujian melalui kata-kata positif.

Dilihat dari fenomena yang terjadi di SDLB Negeri $X$, beberapa orangtua nampak terlalu responsif serta kurang responsif terhadap anak. Hal ini ditunjukan dari beberapa perilaku mereka, seperti kurangnya keterlibatan orangtua dalam pengerjaan tugas-tugas rumah, bimbingan terhadap keterampilan anak sehari-hari, serta kurangnya inisiatif orangtua dalam memantau perkembangan anak. Di sisi lain, ditemukan pula orangtua yang terlihat kurang sabar dalam memberikan suatu pengajaran kepada anak mereka. Hal ini yang kemudian membuat sebagian besar tugas yang diberikan oleh guru dikerjakan sendiri oleh orangtua anak.

Dimensi berikutnya yaitu tuntutan. Tuntutan diartikan sebagai suatu gambaran bagaimana standar yang ditetapkan oleh orangtua bagi anak-anak, berkaitan dengan pengawasan yang diberikan, aturan yang ditetapkan, serta keputusan yang dilakukan orangtua terhadap kegiatan anak (Baumrind dalam Suchman, Rounsaville, DeCoste \& Luthar, 2007). Standar yang ditetapkan oleh orangtua tersebut dapat diartikan sebagai suatu tindakan orangtua dalam membatasi tingkah laku anak. Dalam hal ini, terdapat beberapa orangtua yang terlihat menentukan hal-hal yang harus dilakukan oleh anak dan memberikan batasan terhadap hal-hal yang ingin dilakukan oleh anak. Hal ini tentu saja baik adanya selama orangtua memberikan suatu penjelasan pada anak terkait standar yang ditetapkan tersebut. Untuk itu, pengasuhan yang tepat dapat ditunjukkan saat orangtua memberikan standar yang tepat (sesuai dengan karakteristik anak), diikuti dengan penjelasan, keterbukaan terhadap pendapat anak, serta pemonitoran tingkah laku anak secara berkala.

Dilihat dari fenomena yang terjadi di SDLB Negeri $X$, beberapa orangtua terlihat memiliki tuntutan yang kurang sesuai dengan karakteristik siswa tunagrahita. Contohnya adalah orangtua mengharapkan anak mereka segera dapat membaca dan menulis dengan cepat. Padahal siswa tunagrahita memiliki hambatan dalam pola fikir yang bersifat kompleks (Mangunsong, 2012). Kondisi ini yang membuat mereka kesulitan dalam mengoperasikan suatu bacaan. Dengan demikian, fokus utama pembelajaran mereka yaitu terkait pengasahan perilaku adaptif. Harapan orangtua yang kurang tepat ini dapat menjadi salah satu hambatan bagi para siswa tunagrahita dalam mengasah perilaku adaptifnya sehari-hari

Berdasarkan fenomena yang terjadi di SDLB Negeri X, peneliti ingin melihat lebih lanjut terkait sejauh mana gambaran pengasuhan ibu yang diberikan kepada para siswa, khususnya dalam mengembangkan perilaku adaptif. Hal ini karena pengasuhan ibu dianggap sebagai faktor utama yang dapat mempengaruhi berbagai keterampilan anak (Bowly, dalam Shaver \& Cassidy, 2016). Pada penelitian ini, keterampilan yang dimaksud yaitu terkait perilaku adaptif para siswa tunagrahita. Adanya penelitian ini pula, peneliti berharap dapat memperoleh kendalakendala yang dirasakan oleh para ibu terkait pengasuhan terhadap para siswa, sehingga pada akhirnya peneliti dapat menemukan saran yang tepat untuk mengatasi kendala yang mungkin dialami oleh para ibu. 


\section{METODE}

Peneliti menggunakan jenis penelitian kualitatif dalam penelitian ini. Hal ini karena peneliti berupaya untuk mendalami sudut pandang individu yang menjadi partisipan penelitian (Poerwandari, 2011). Pendalaman sudut pandang tersebut hanya dapat dilakukan pada penelitian kualitatif. Dengan demikian, peneliti memilih jenis penelitian kualitatif. Untuk metode pengumpulan data, peneliti menggunakan teknik wawancara dan observasi. Tujuan dari teknik wawancara ini yaitu untuk menggali gambaran respon serta tuntutan yang diberikan oleh para responden kepada anak mereka. Selain itu, peneliti juga ingin menggali terkait gambaran perilaku adaptif yang dimiliki oleh para siswa tunagrahita. Selanjutnya, untuk data observasi, peneliti hanya menggunakannya sebagai penunjang keabsahan data wawancara. Dengan demikian, data observasi hanya sebagai data pelengkap hasil wawancara.

Jenis wawancara yang digunakan yaitu wawancara mendalam (indepth interview), yaitu wawancara yang berdasarkan pada pedoman, namun tetap tidak seketat dalam wawancara terstruktur. Pedoman wawancara juga akan berisi pertanyaan-pertanyaan terbuka sebagai pendekatan dasar dalam perolehan suatu data. Dengan demikian, penelti menggunakan pedoman tertulis serta alat perekam untuk proses wawancara. Proses wawancara tersebut dilakukan di dua setting tempat yaitu di rumah dan di sekolah.

Selanjutnya, metode observasi digunakan untuk melihat aktivitas ketiga partisipan saat berinteraksi dengan anak mereka. Untuk penelitian ini, penulis akan menjadi pengamat pasif dalam melakukan observasi. Tujuan lainnya yaitu untuk melihat sejauh mana kesesuaian data wawancara dengan kondisi lapangan. Dalam hal ini, peneliti juga memiliki pedoman observasi. Pedoman observasi disusun dengan konsep-konsep teoritis dalam penelitian ini. Hal-hal yang dilihat dari penelitian ini yaitu terkait dengan teori pengasuhan ibu dan tunagrahita usia sekolah dasar. Sama seperti panduan wawancara, setelah penulis selesai dalam menyusun panduan observasi, penulis meminta expert judgement untuk mendapatkan umpan balik terhadap pedoman. Sama halnya dengan metode wawancara, peneliti melakukan metode observasi di sekolah maupun rumah. Tujuannya yaitu untuk mendapatkan gambaran keseluruhan perilaku adaptif siswa tunagrahita.

Partisipan dalam penelitian ini dipilih secara purposive. Artinya, partisipan penelitian dipilih berdasarkan kecocokan dengan konteks penelitian, sehingga diperkirakan memiliki informasi yang dibutuhkan untuk menjawab tujuan penelitian (Kumar, 2005). Dalam pemilihan partisipan ini, peneliti melakukan diskusi dengan pihak sekolah. Kriteria dari partisipan penelitian yaitu mereka yang miliki pengasuhan yang kurang optimal serta memiliki anak tunagrahita dengan kapasitas intelektual sedang hingga berat. Berdasarkan hasil diskusi, peneliti menemukan tiga partisipan yang paling sesuai dengan konteks penelitian.

Partisipan pertama berusia 56 tahun dengan pendidikan terakhir diploma (D3). Partisipan kedua berusia 42 tahun dengan pendidikan terakhir SMP. Partisipan ketiga berusia 54 tahun dengan pendidikan terakhir SMA. Ketiga partisipan merupakan ibu rumah tangga.

Dalam prosedur analisis, langkah awal yang dianalisis yaitu membaca hasil wawancara yang telah dituliskan dalam bentuk verbatim. Setelah itu, penulis mencoba untuk menganalisis hasil tersebut. Dilihat dari jawaban-jawaban yang diutarakan oleh partisipan, penulis mencoba untuk mengkatagorikan jawaban-jawaban tersebut sesuai dengan aspek-aspek yang diteliti, yaitu responsivitas dan tuntutan. Pengasuhan ini tentu saja lebih berkaitan dengan pengasahan perilaku adaptif yang dilakukan oleh para ibu (dilihat dari masing-masing bagian 
kemampuan adaptif siswa). Selanjutnya, penulis menggabungkan hasil analisa dan interpretasi dari data wawancara dengan hasil observasi. Hasil analisa dan interpretasi ini menjadi dasar pertimbangan penulis dalam menarik kesimpulan penelitian dan menyusun rancangan intervensi.

\section{HASIL DAN PEMBAHASAN}

Dalam menemukan gambaran responsivitas serta tuntutan ibu, peneliti melakukan teknik coding terlebih dahulu. Teknik coding ini merupakan suatu teknik dalam menemukan sebuah kata singkat yang memuat esensi dari suatu segmen data (Poerwandari, 2011). Sebelum melakukan coding tersebut, peneliti melakukan verbatim pada setiap hasil wawancara maupun observasi. Tujuannya adalah untuk mempermudah peneliti dalam melakukan coding serta menentukan tema pembahasan. Berdasarkan hasil coding tersebut, peneliti menemukan beberapa tema yang menggambarkan pengasuhan ibu. Coding pertama yaitu terkait responsivitas yang ditunjukkan ibu kepada siswa tunagrahita. Berdasarkan hasil coding, peneliti menemukan tiga tema, antara lain respon ibu terkait kebutuhan anak, keterlibatan yang ditunjukkan oleh ibu terkait aktivitas anak, serta afeksi yang diberikan oleh ibu kepada anak. Hasil ini diperoleh dari data wawancara maupun observasi.

Dilihat dari ketiga partisipan, mereka nampak belum menerapkan pembelajaran yang sesuai dengan kebutuhan anaknya. Hal ini terlihat dari perilaku yang ditunjukkan oleh ketiga partisipan saat memberikan pengajaran terkait perilaku adaptif kepada masing-masing anak.

"Ya umumnya dilakukan dengan katakata aja ya, dikasih tau ke anaknya."

"Ya gak tentu, pokoknya saat apa saja"

"Ya kalau bersihin kuping saya cuma bilang ke dia suruh pakai sabun mandi aja. Digosok dikuping, kadang masih suka nempel di kuping”"
Secara umum, ketiga partisipan nampak memberikan pengajaran secara verbal saja. Selain itu, ketiga partisipan juga belum memberikan pembelajaran atau latihan secara konsisten kepada masing-masing anak. Pembelajaran dilakukan hanya di waktu tertentu saja. Kondisi ini didukung dengan hasil observasi yang dilakukan di rumah atau sekolah. Berdasarkan hasil observasi, ketiga patisipan terlihat memberikan instruksi verbal saat pembelajaran perilaku adaptf. Hal ini tentu bertolak belakang dengan karakteristik siswa tunagrahita. Menurut Suparno (dalam Helawati, 2016), siswa tunagrahita memerlukan pembelajaran yang bersifat konkret (peragaan), pemberian latihan secara konsisten, pengulangan materi, serta pemberian reward. Keempat prinsip pembelajaran tersebut nampak tidak ditunjukkan oleh ketiga partisipan.

Adanya pembelajaran yang kurang sesuai ini sebenarnya berkaitan dengan beberapa faktor. Salah satu faktor yang mempengaruhi yaitu tingkat pendidikan orangtua. Menurut Hurlock (2000), semakin tinggi tingkat pendidikan orangtua ternyata berdampak pada pengasuhan yang diberikan oleh orangtua kepada anak. Hal ini karena orangtua yang memiliki pendidikan tinggi, mereka cenderung memiliki modalitas yang cukup dalam mendidik serta merawat anak. Hurlock (2000) juga menyebutkan bahwa ketika pendidikan orangtua rendah, orangtua cenderung menerapkan pengasuhan yang permisif. Dengan demikian, bentuk respon yang dimunculkan antara lain perilaku tidak mengontrol anak, tidak memberikan hukuman, serta terlihat memberikan izin bagi anak untuk beringkah laku sesuai dengan keinginan anak.

"Masih perlu dibantu kebanyakan. Habis saya daripada dia nangis. Sedih juga lihatnya kalau dia nangis"

"Ya pada sayang sama dia. Kalau minta apa juga jadinya diturutin. Kakaknya juga gitu." 
Hal ini didukung dari perolehan hasil observasi. Ketiga partisipan terlihat membantu serangkaian aktivitas anak seharihari. Contohnya terkait aktivitas makan. Satu dari tiga partisipan terlihat membantu siswa tunagrahita untuk mengambil makanan serta memasukkan makanan tersebut ke dalam mulut anak.

Adapun bentuk respon yang ditampilkan memiliki beberapa perbedaan. Salah satu faktor yang dapat mempengaruhi yaitu latar belakang pendidikan. Partisipan pertama memiliki latar belakang pendidikan lebih tinggi dibandingkan dengan kedua partisipan lainnya. Hal ini yang membuat adanya perbedaan pembelajaran antara partisipan pertama dengan kedua partisipan lainnya. Partisipan pertama terlihat memberikan suatu penghargaan kepada anak saat anak berhasil melakukan sesuatu yang diharapkan. Bentuk penghargaan dilakukan secara verbal maupun gerakan tubuh. Perilaku ini yang tidak ditunjukkan pada kedua partisipan lainnya.

"Ya itu dari gerakan jempol aja. Kalau dia bilang bagus ya nunjukin jempol ke saya. Saya bilang belum baru 1 jempol kalau dia belum sempurna. Biar dia berusaha lagi. Terus besoknya kalau hasilnya dia hasilnya bisa atau bagus. Dia kasih jempolnya 2. Kalau saya bilang hasilnya belum bagus, saya kasih 1. Bilang belum, saya bilang besok segini ya (dua jempol), sekarang segini (satu jempol)."

Ketidaksesuaian respon juga nampak dari bentuk keterlibatan yang diberikan oleh ketiga partisipan. Ketiga partisipan terlihat memberikan keterlibatan yang kurang sesuai dengan karakteristik anak tunagrahita.

"Iya langsung saya pakaikan. Habis lama kalau dia. Telat yang ada kemana mana pergi."

"Iya bisa cuma lama banget. Saya-nya gak sabar. Jadi ya saya bantuin aja udah. Saya pakein."
Dilihat dari hasil perolehan data, ketiga partisipan nampak memberikan keterlibatan penuh pada aktivitas keseharian anak. Bahkan pada aktivitas-aktivitas yang sudah dikuasai oleh anak. Keterlibatan penuh ini sebenarnya dipengaruhi oleh beberapa faktor. Salah satunya yaitu anggapan orangtua bahwa anak tunagrahita tidak memiliki kemampuan untuk mempelajari keterampilan tertentu (Mangunsong, 2012). Padahal dilihat dari segi kemampuan, anak tunagrahita memiliki kemampuan untuk melakukan kegiatan harian secara mandiri.

"Dia gak bisa kalau mandi sendiri, pasti gak bersih, jadi ya saya bantu terus, diajarin juga percuma gak bisabisa anaknya. Emang begitu mungkin anaknya susah"

"Kalau motong makanan susah dia, pasti saya harus bantu, kalau gak ya pasti di langsung makan aja, mau porsinya besar langsung disuap. Mau saya udah ajarin juga percuma susah kayaknya anaknya emang gak mampu mungkin."

Kesulitan pengajaran yang dirasakan oleh ketiga partisipan juga menjadi salah satu kendala bagi mereka dalam menentukan bentuk keterlibatan yang tepat. Hal ini sesuai dengan pernyataan yang diungkapkan oleh Westwood (2010), yaitu orangtua dengan anak disabilitas cenderung merasakan tantangan yang lebih besar dalam pengasuhan anak. Akibatnya, orangtua cenderung merasa lebih kesulitan dibandingkan dengan mengasuh anak mereka yang memiliki perkembangan normal.

"Kalau tepat saya gak tau. Kan dia berfikirnya belum. Akalnya kurang. Saya takut kalau dia kepotong atau kena api. Beda kalau kakaknya dulu saya lebih berani, lebih bisa mudah ngerti kitanya. Kalau sih FD mah saya takut. Saya ngerasa lebih susah buat ngajarinnya juga" 
Kesulitan yang dirasakan oleh para partisipan juga berdampak pada parenting self efficacy mereka. Hal ini karena kegagalan yang terus menerus dimunculkan oleh anak justru membuat ketiga partisipan tidak memiliki keyakinan dalam mengasuh anak. Dilihat dari pengertiannya, parenting self efficacy merupakan persepsi orangtua mengenai kemampuan mereka untuk secara positif mempengaruhi perilaku dan perkembangan anak mereka (Coleman \& Karrakker, dalam Junttila, Vauras, \& Laakkonen, 2007). Dilihat dari ketiga partisipan, mereka cenderung tidak merasa yakin dengan kemampuan mereka untuk mengasuh anak mereka. Hal ini terjadi karena masalah perilaku anak yang muncul sehari-hari.

Menurut Coleman dan Karrakter (dalam Junttila, Vauras, \& Laakkonen, 2007), ketika anak menunjukkan masalah perilaku tertentu, maka orangtua cenderung merasa kurang berkompeten dalam menjalankan peran sebagai orangtua. Dilihat dari ketiga partisipan, adanya ketidakberhasilan dalam memberikan pengajaran pada anak justru mempengaruhi parenting self efficacy mereka. Hal ini yang membuat mereka cenderung tidak mampu untuk bertahan dalam mengatasi rintangan yang ada. Kondisi ini yang membuat ketiga partisipan mengandalkan pihak guru dalam memberikan pengajaran kepada anak. Dengan demikian, ketiga partisipan mengandalkan pengawasan pihak guru untuk mendapatkan informasi terkait kemajuan serta perkembangan anak.

"Padahal yang paling ngerti kan guru. Orangtua kan gak tau gimana ngajarin anak gini. Kalau mereka kan belajar di sekolah mungkin."

"Ya saya sudah mempelajari semampu saya, tapi kalau perkembangannya sama ahlinya juga. Perkembangan ke depannya sama ahlinya. Untuk perkembangan selanjutnya, ia harus belajar di sekolah. Dari sekolah kita bisa menerapkannya di rumah. Saya udah mengembangkan seluruh kemampuan saya. Udah sebisa saya semampu saya"

Gambaran respon yang ditunjukkan oleh ketiga partisipan juga dilihat dari bagaimana afeksi yang diberikan oleh ketiga partisipan kepada masing-masing siswa. Dilihat dari perilaku yang ditunjukkan, ketiga partisipan nampak memberikan kasih sayang kepada masing-masing anak. Ketiga partisipan nampak memberikan afeksi berupa bantuan langsung kepada masing-masing anak di serangkaian aktivitas.

"Ya sayang, ya saya coba menampilkan kasih sayang saya lewat perbuatan saya. Saya nyiapin kebutuhan dia, bantuin dia ini itu. Saya sampai mikir kalau gak ada saya gimana anak saya. Apa bisa dia hidup tanda bantuan saya"

Dimensi pengasuhan berikutnya yaitu tuntutan. Menurut Baumrind (dalam Alizadeh, Talib, Abdullah, \& Mansor, 2011), tuntutan diartikan sebagai sejauh mana orangtua memberikan standar tertentu kepada masing-masing anak. Standar tersebut mengacu pada aturan-aturan yang ditetapkan orangtua, pengawasan yang dilakukan, serta keputusan yang diberikan oleh orangtua terkait aktivitas anak. Ketiga standar ini merupakan tema-tema yang diperoleh dari hasil pengolahan data wawancara serta obserasi.

Dilihat dari tuntutan yang ditunjukkan, ketiga partisipan nampak belum menerapkan standar yang sesuai dengan kebutuhan serta karakteristik anak tunagrahita. Hal ini nampak dari aturan yang diberikan oleh para ibu kepada ketiga anak masing-masing.

"Gak sih ya gak ada. Kalau makan juga saya bebasin mau pake sendok apa tangan. Gak ada aturan khusus harus bagaimana HF nya"

"Gak sih ya. Waktu mandi aja, pagi dan sore. Udah sih itu aja. " 
Aturan tersebut terlihat tidak berkaitan dengan perilaku adaptif yang perlu dikembangkan oleh masing-masing anak. Padahal masing-masing anak memiliki beberapa keterampilan perilaku adaptif yang perlu dikembangkan. Contohnya yaitu terkait kebersihan diri. Sebagian besar partisipan hanya memberikan aturan yang bersifat umum kepada siswa tunagrahita. Dengan demikian, aturan tersebut memiliki kesamaan dengan aturan yang diberikan oleh saudara kandung anak. Padahal ketiga siswa tunagrahita belum mampu untuk membersihkan tubuhnya secara mandiri. Namun aturan yang ditetapkan hanya terkait waktu membersihkan diri.

Tidak hanya itu saja, aturan yang diberikan juga tidak diimbangi dengan penjelasan yang konkrit. Padahal menurut Hallahan, Kauffman, dan Pullen (2012), adanya kemampuan intelektual anak tunagrahita yang terbatas membuat anak kesulitan untuk memahami hal-hal yang bersifat abstrak. Dengan demikian, aturan yang diberikan kepada anak tunagrahita perlu dijelaskan secara konkrit dan sederhana. Namun dilihat dari ketiga partisipan, sebagian besar aturan yang diberikan tidak dijelaskan secara konkrit dan sederhana.

"Secara lisan saja biasanya untuk kasih tau aturan. Cuma ya itu kadang didengerin kadang dianggap lalu saja sama anak. Jadi kita mesti ingetin terus.

Beberapa aturan juga nampak belum sesuai dengan karakteristik anak tuna garahita. Hal ini terlihat dari aturan yang diberikan oleh dua dari tiga partisipan penelitian. Kedua partisipan nampak memberikan aturan kepada anak agar segera dapat membaca dengan lancar seperti anak lain pada umumnya.

"Saya pengennya anak saya bisa baca tulis hitung kalau mamanya"
Padahal dilihat dari karakteristik anak tunagrahita sedang hingga berat, mereka cenderung mengalami kesulitan untuk mempelajari hal-hal yang bersifat abstrak, seperti hitungan ataupun membaca (Mangunsong, 2012). Dengan demikian, fokus pembelajaran bagi anak tunagrahita yaitu terkait keterampilan dasar sehari-hari.

Ketiga partisipan juga tidak memberikan pengawasan yang rutin terhadap serangkaian aktivitas anak sehari-hari. Sebagian besar partisipan nampak tergantung dengan informasi yang ditunjukkan oleh pihak guru. Kondisi ini ditemukan di ketiga partisipan. Hal ini yang membuat ketiga anak partisipan memiliki keterbatasan dalam beberapa perilaku adaptif mereka.

"Ya kadang suka nanya ada peer gak kalau di kelas. Setelah itu ya gak ada pertanyaan apa-apa"

"Gak tau juga ya saya. Gak liat juga saya waktu gurunya ngajar. Saya juga gak nanya ke gurunya”.

Terkait dengan keputusan yang diberikan, ketiga partisipan nampak memberikan kesempatan bagi anak untuk memilih apa yang diinginkan oleh masing-masing anak mereka. Bahkan salah satu partisipan nampak menuruti apapun yang menjadi kehendak anaknya. Kondisi ini yang menggambarkan pengasuhan yang permisif pada anak.

"Kalau dia minta suapin, ya saya suapin dibanding gak habis"

"Iya dibeliin juga apa yang dimauin dia."

"Ya teriak manggil minta tolong kancingin. Ya samperin. Ya udah dibantuin"

Kondisi ini juga didukung oleh hasil observasi. Berdasarkan hasil observasi, ketiga partisipan terlihat memberikan segala sesuatu yang diminta oleh ketiga anak mereka. Contohnya yaitu pada aktivitas berpakaian. Ketika siswa tunagrahita terlihat kesulitan untuk memakai kancing baju, 
partisipan penelitian terlihat memberikan bantuan langsung kepada anak.

\section{SIMPULAN}

Ketiga partisipan nampak belum menampilkan pengasuhan yang optimal bagi para siswa tunagrahita. Hal ini terlihat dari responsivitas yang ditunjukkan serta tuntutan yang diberikan oleh para ibu kepada anak. Responsivitas ditunjukkan dari respon yang kurang tepat terkait kebutuhan siswa, keterlibatan yang kurang sesuai dengan karakteristik anak, serta afeksi yang kurang tepat terhadap anak. Kondisi yang sama juga terkait tuntutan. Ketiga partisipan terlihat memiliki standar yang kurang sesuai dengan kebutuhan anak, pengawasan yang kurang optimal, serta keputusan yang kurang tepat bagi siswa tunagrahita. Kondisi ini yang membuat keterampilan perilaku adaptif anak belum dapat berkembang optimal dan masih tingginya ketergantungan anak terhadap orang-orang sekitarnya. Saran penulis berdasarkan penelitian ini adalah perlunya pemberian wawasan bagi para ibu untuk meningkatkan pengasuhan yang lebih optimal bagi anak tunagrahita dan perlunya pihak sekolah menciptakan situasi yang dapat membangun perilaku adaptif anak.

\section{DAFTAR PUSTAKA}

Agustin, L. D., \& Widyawati, Y. (2012). Peran ibu dalam mengembangkan penguasaan perilaku adaptif anak tunagrahita. Manasa, 1(2), 196-202.

Alizadeh, S., Talib, M. B. A., Abdullah, R., \& Mansor, M. (2011). Relationship between parenting style and children's behavior problems. Asian Social Science, 7(12), 195-200. http://dx.doi.org/10.5539/ass.v7n12p1 95.

Boundarant-Utz, J. A., \& Luciano, L. B. (1997). A practical guide to infant and preschool assessment in special education. Massachusettts: Allyn and Bacon.
Dyches, T. T., Smith, T. B., Korth, B. B., Roper, S. O., \& Mandleco, B. (2012). Positive parenting of children with developmental disabilities: A metaanalysis. Research in Developmental Disabilities, 33(6), 2213-2220. https://doi.org/10.1016/j.ridd.2012.06 .015

Eisenberg, N., Zhou, Q., Spinrad, T. L., Valiente, C., Fabes, R. A., \& Liew, J. (2005). Relations among positive parenting, children's effortful control, and externalizing problems: A threewave longitudinal study. Child Development, 76, 1055-1071.

Hallahan, D. P., Kauffman, J. M., \& Pullen, P. C. (2012). Exceptional Leaners: An introduction to special education. Boston: Pearson.

Helawati, L. (2016). Modul pembelajaran SLB tunagrahita. Bandung: Pusat Pengembangan dan Pemberdayaan Pendidik dan Tenaga Kependidikan Bidang Pendidikan Luar Biasa.

Heward, W. (2013). Exceptional children: An introduction to special education (10 ${ }^{\text {th }}$ edition). USA: Pearson.

Hong, S. O., Long, S. C., \& Rahman, R. H. (2015). An analysis on relationship between parenting styles and self esteem of students of a university in Malaysia: A case study. Mediterranean Journal of Social Sciences, 6(4), 300-310. doi: 10.5901/mjss.2015.v6n4s3p300

Hurlock, E. B. (2000). Psikologi perkembangan. Jakarta: Penerbit Erlangga.

Junttila, N., Vauras, M., \& Laakkonen, E. (2007). The role of parenting self efficacy in children's social and academic behavior. European Journal 
of Psychology of Education, 22(1), 41-61.

Kementerian Sosial. (2015). Survey Sosial Ekonomi Nasional Tahun 2016. Jakarta: Badan Pusat Statistik.

Ling, F. (2008). Self-care behaviors of school-aged children wih heart disease. Pediatric Nursing Journals, 34(2), 131-138.

Mahdavi, N., Esmaeilpour, K., \& Khajeh, V. (2013). Parenting style and dimension of children's maladaptive behavior, Journal of Practice in Clinical Psychology, 1(3), 163-168.

Mangunsong, F. (2012). Psikologi dan pendidikan anak berkebutuhan khusus. Depok: Kampus Baru UI.

Poerwandari, E. K. (2011). Pendekatan kualitatif untuk penelitian perilaku manusia. Jakarta: LPSP3 UI.

Shaver, P. R., \& Cassidy, J. (2016). Handbook of attachment: Theory, research, and clinical application. New York: The Guilford Press.
Suchman, N. E., Rounsaville, B., DeCoste, C., \& Luthar, S. (2007). Parental control, parental warmth, and psychosocial adjustment in a sample of substance-abusing mothers and their school-aged and adolescent children. Journal of Substance Abuse Treatment, 32(1), $1-10$. DOI:10.1016/j.jsat.2006.07.002

Tork, H., Lohrmann, C., \& Dassen, T. (2007). Care dependency among school-aged children: Literature review. Nursing and Health Sciences, 9(2), 142-149. DOI: $10.1111 / \mathrm{j} .1442-$ 2018.2007.00313.x

Westwood, W. K. (2010). Children with mental retardation/ intellectual disability: The function of adaptive behavior and parental stress acroos childhood. Pennsylvania: Duquesne University.

Wolfe, D. A., \& Mash, E. J. (2010). Abnormal child psychology. United Kingdom: Wadsworth Cengage Learning. 